ADVOCACY IN ACTION

Advocacy in action: extreme corporate makeover
interruptus: denormalising tobacco industry corporate
schmoozing

S Chapman

Tobacco Control 2004;13:445-447. doi: 10.1136/tc.2004.010025

The tobacco industry continues to seek corporate "respectability", despite being responsible for the deaths of millions of smokers worldwide every year

I

n May 1998, the tobacco industry's world was turned upside down by a judgment in the Minnesota court that in part required US tobacco companies to make public millions of pages of previously internal documents. As the Minnesota judgment threatened to domino through different US state copycat trials, the tobacco industry struck the historic Master Settlement Agreement (MSA) with the US state attorneys general in November 1998. The MSA provided for $\$ 206$ billion to be paid by the companies to the states, and significantly, that all documents "discovered" in any trial up until 2010 be placed on the world wide web. Today, some 40 million pages of previously private memos, faxes, reports, and letters are available to anyone with a computer (see http://legacy. library.ucsf.edu/).

Faced with this Niagara of embarrassing revelations, including thousands from its highest officials, the international industry changed strategy. It embarked on the world's most public rebirthing exercise, asking to henceforth be appreciated as an ethical industry devoted to providing tobacco products to sentient adults, all supposedly fully informed of the risks they took. No longer was the relation between smoking and illness merely a dubious "statistical association", the new tobacco industry now admits in carefully weasel worded statements that tobacco use is a highly risky practice. As British American Tobacco (BAT) carefully put it this year in its 2003/4 Social Report: "Our main role is to recognise the relevant health authorities as the prime public voice on the health risks of tobacco consumption, while at the same time making our views clear."1 Translated, this might mean: "Like everyone else, we can see it is a fact that health authorities are the main voice on smoking and health. We 'recognise' this, but we also have 'our views' on smoking and health and we'll take every opportunity to make them clear to governments trying to do heinous things like place graphic photos of tobacco diseases on packs." In 2004, BAT Australia, for example, fresh from gushing about its dedication to informing smokers about risk, lobbied hard to dissuade governments to shelve plans for these warnings, including funding of retail petitions where its role was not acknowledged. ${ }^{2}$

For the rebirthed industry, no longer was nicotine a simple "habit" akin to liking chewing gum, chocolate, or television viewing, BAT now concedes "The common understanding is that nicotine is addictive". ${ }^{1}$ Translated, this means: "We concede that everyone says nicotine is addictive, but we don't necessarily agree. And if someone claims in court they were addicted to our products, we'll probably keep on doing what we have been doing for years and challenge that, pointing to all the ex-smokers in the community."

There is wholesale cynicism and disgust in health and medical circles about this exercise. Critics point out that contrary to the most elementary procedures for wrongdoers seeking public contrition, the industry has made no public apology about its years of misleading conduct to accompany its volte face. Doubtless mindful of the legal ramifications of doing so, it has made no admissions that it lied to smokers in the past, and that for decades it engaged in a globally orchestrated campaign to falsely reassure smokers. It has made no gestures to compensate those it has harmed. It remains implacable in its refusal to acknowledge that intriguing children about smoking is intrinsic to its continuing future economic welfare. Indeed it is so sincere in not wanting children to smoke, that it refuses to hand back its annual massive earnings from underage smokers, whom it says ad nauseum it doesn't want to smoke.

\section{DENORMALISATION IN ACTION}

Emboldened in their fetching new sheepskins, and refreshed from sipping homeopathic strength truth serum, tobacco industry wolves are doing the rounds of the world's corporate responsibility conferences. On 26 May 2004, corporate responsibility watcher Bert Hirschhorn $^{3}$ noticed that BAT and Philip Morris were getting home page billing as speakers and gold sponsors (fig 1) at a conference to be held in Hong Kong in October 2004 run by Ethical Corporation magazine. ${ }^{4}$ Email alerts saw tobacco control activists Mary Assunta from Malaysia and Professor Tony Hedley from Hong Kong contact Asian delegates listed as speaking at the conference. Hedley also protested to his university chancellor over the involvement of his university's business school in the event.

Stan Shatenstein and I set up an online petition on Globalink for professional ethicists 

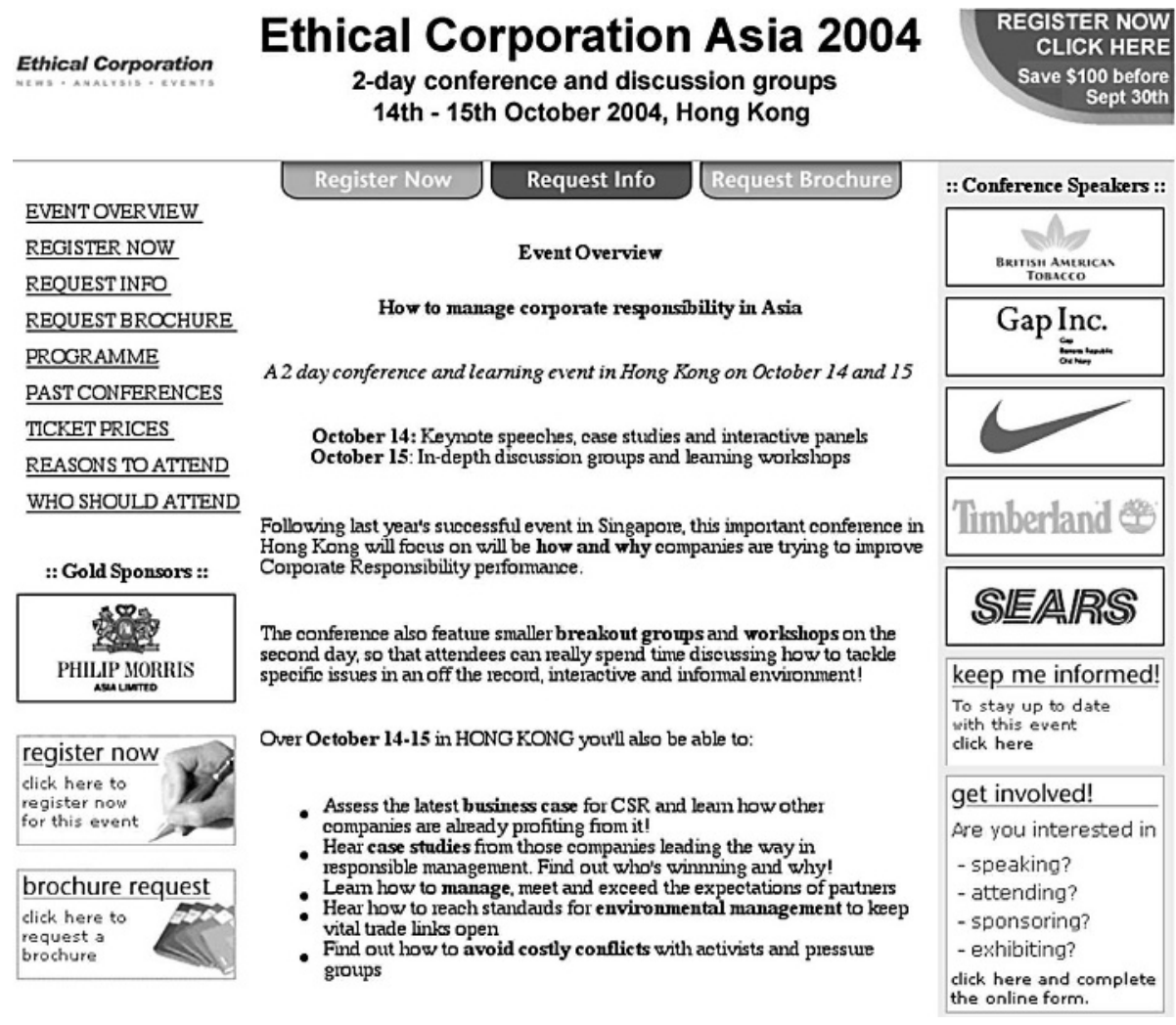

Figure 1 Top billing for Philip Morris and BAT on the home web page of Ethical Corporation Asia 2004.

to condemn the tobacco industry's involvement. ${ }^{5}$ I emailed the link to colleagues in my own university's Department of Philosophy inviting them to sign and to then forward the link to the petition to their international colleagues in ethics. Within days, some 86 ethicists had signed, including bioethics heavyweights Peter Singer from Princeton University and Arthur Kaplan from the University of Pennsylvania.

The two tobacco companies disappeared from the conference website within a week of the campaign commencing. Staff at Ethical Corporation advised us that they had received heated complaints about tobacco industry involvement and that they had advised Philip Morris that their sponsorship was cancelled and were considering whether to cancel BAT's speaking role: "This furore made us realise that there are some companies who we cannot take sponsorship money from, this list of industry sectors, along with tobacco, includes defence, nuclear and biotechnology." Two speakers withdrew from the conference in protest and the conference went ahead without tobacco involvement.

A second opportunity arose to test this strategy in July in Sydney when a website advertising the "Australian Public Relations and Corporate Communications Summit 2004" showed a Philip Morris representative on the programme. All speakers were emailed a letter signed by myself and the head of the Cancer Council New South Wales, Dr Andrew Penman. We wrote, in part:

"This conference is giving a stage to a company to gloat about its "strategies" and to portray itself in a good light. Philip Morris has been engaging in a global program of spending vast sums of money to publicise its support for programs like domestic violence awareness, carefully selected to ensure that it is largely immune from criticism. In Australia it has even funded an Aboriginal health promotion campaign, knowing well that our indigenous populations have among the highest smoking rates in the country.
"It funds highly-publicised youth smoking prevention programs, yet is content to keep the large amounts of revenue it derives from under-age smokers each year.

"We are writing to all keynote speakers to urge you to put pressure on the organizers of this conference to have Philip Morris removed from the program. If the organizers do not agree to this, we would urge you to withdraw your own participation. We will be seeking to bring maximum publicity to our efforts to urge all other speakers to withdraw and hope that we will be able to highlight your responsible action in this matter.

"In considering your participation, you may wish to consider whether you and your organization would be prepared to speak at a conference that had also invited an arms dealer to speak. Or a mercenary recruitment agency. Or the public relations division of a despotic nation. Or the gun lobby. Or a racist political party. Each of these organizations are, like tobacco companies, also "legal"."

At least two prominent business speakers contacted the organisers, threatening to withdraw should Philip Morris remain on the programme. The organisers promptly "deinvited" Philip Morris from the programme.

\section{WHY SO EASY?}

The speed by which the organisers of both conferences showed their already invited tobacco industry sponsors and speakers the back door was remarkable. Despite Philip Morris being a "gold sponsor", a simple show of protest consisting of a few emails and phone calls was sufficient to abort their involvement in both conferences.

The tobacco industry has had many doors closed in its face over the years. The BAT Social Report shows that no UK public health or tobacco control groups chose to participate in its consultations (reference 1, page 16). Similar refusal to buy into the industry's oleaginous talk about dialogue with 
stakeholders has occurred in other nations, with groups and individuals refusing to risk being appropriated into the industry's public relations ambitions. It now looks like that with vigilance, tobacco control advocates can easily foment similar distaste in many areas of the business community. Our actions sought to denormalise the tobacco industry by disrupting its efforts to take its place alongside other industries-often with considerable social credit-in the hope that it might gain by association.

Tobacco industry posturing about its corporate responsibility can never hide the ugly consequences of its ongoing efforts to "work with all relevant stakeholders for the preservation of opportunities for informed adults to consume tobacco products"1 (translation: "we will build alliances with others who want to profit from tobacco use, to do all we can to counteract effective tobacco control"). BAT has $15.4 \%$ and Philip Morris $16.4 \%$ of the global cigarette market. ${ }^{6}$ With 4.9 million smokers currently dying from tobacco use each year, and the industry unblinkingly concurring that its products are addictive, this leaves BAT to argue why it should not be held to be largely accountable for the annual deaths of some 754600 smokers, and Philip Morris some 803600 smokers.

\section{REFERENCES}

1 British American Tobacco. Social Report. http://www.bat.com/204pp.

2 Wroe D. Tobacco ad campaign angers MPs. The Age (Melbourne) 2004; May 17 http://www.theage.com.au/articles/2004/05/16/ 1084646069771.html?oneclick = true.

3 Hirschhorn N. Corporate social responsibility and the tobacco industry: hope or hype? Tobacco Control 2004:13:447-53.

4 Ethical Corporation Asia 2004. Conference website. http:// www.ethicalcorp.com/asia2004/.

5 Chapman S, Shatenstein S. Extreme corporate makeover: tobacco companies, corporate responsibility and the corruption of "ethics". Globalink petition. http://petition.globalink.org/view.php?code = extreme.

6 Mackay J, Eriksen M. The tobacco atlas. Geneva: World Health Organization, 2002

INDUSTRY WATCH

\title{
Corporate social responsibility and the tobacco industry: hope or hype?
}

\author{
N Hirschhorn
}

Tobacco Control 2004;13:447-453. doi: 10.1136/tc.2003.006676

Corporate social responsibility (CSR) emerged from a realisation among transnational corporations of the need to account for and redress their adverse impact on society: specifically, on human rights, labour practices, and the environment. Two transnational tobacco companies have recently adopted CSR: Philip Morris, and British American Tobacco. This report explains the origins and theory behind CSR; examines internal company documents from Philip Morris showing the company's deliberations on the matter, and the company's perspective on its own behaviour; and reflects on whether marketing tobacco is antithetical to social responsibility.

\section{Correspondence to: Dr Norbert Hirschhorn Nastolantie 6, A3 00600 Helsinki, Finland; bertzpoet@yahoo.com \\ Received \\ 13 November 2003 \\ Accepted 15 July 2004}

O ver the past three decades increasing pressure from non-governmental organisations (NGOs), governments and the United Nations, has required transnational corporations (TNCs) to examine and redress the adverse impact their businesses have on society and the environment. Many have responded by taking up what is known as "corporate social responsibility" (CSR); only recently have two major cigarette companies followed suit: Philip Morris (PM) and British American Tobacco (BAT). This report first provides the context and development of CSR; then, from internal company documents, examines how PM came to its own version. This paper examines whether a tobacco company espousing CSR should be judged simply as a corporate entity along standards of business ethics, or as an irretrievably negative force in the realm of public health, thereby rendering CSR an oxymoron.

\section{CORPORATE SOCIAL RESPONSIBILITY: THE CONTEXT}

The term "corporate social responsibility" is in vogue at the moment but as a concept it is vague and means different things to different people. ${ }^{1}$

Some writers on CSR trace its American roots to the 19th century when large industries engaged in philanthropy and established great public institutions, a form of "noblesse oblige". But the notion that corporations should be required to return more to society because of their impact on society was driven by pressures from the civil rights, peace, and environmental movements of the last half century. ${ }^{23}$ The unprecedented expansion of power and influence of TNCs over the past three decades has accelerated global trade and development, but also environmental damage and abuses of

Abbreviations: ASH, Action on Smoking and Health; BAT, British American Tobacco; CERES, Coalition for Environmentally Responsible Economies; CSR, corporate social responsibility; DJSI, Dow Jones Sustainability Index; GCAC, Global Corporate Affairs Council; GRI, Global Reporting Initiative; MSA, Master Settlement Agreement; NGOs, non-governmental organisations; PM, Philip Morris; TNCs, transnational corporations; UNEP, United Nations Environment Program 
human rights in factories and corporate agriculture. Union Carbide in Bhopal, the Exxon Valdez oil spill, Royal Dutch/ Shell Group behaviour in Nigeria, Nike sweatshops in Vietnam, Nestle marketing of powdered milk formula in developing countries, among others, energised the newly vibrant community of NGOs. These groups began to demand accountability from the TNCs beyond annual reports of profit and loss to include the economic, legal, environmental and social impacts of their businesses, backing up their demands with boycotts, publicity, and litigation. Some institutional and mutual fund purchasers of TNCs' public stock began to screen which shares to buy under the rubric of "socially responsible investing" (SRI). In response some TNCs began to issue expanded public reports variously named "social reporting", "triple bottom line" (economic, legal, social), "corporate citizenship", and "corporate social responsibility". Such accountability receives the imprimatur of the world community through the United Nations' Global Compact, which brings together UN agencies, business, labour, and civil society organisations around nine principles modelling voluntary corporate social responsibility for human and labour rights and the environment. No tobacco company has signed on to the Global Compact. ${ }^{4}$

Attitudes toward CSR range widely. Milton Friedman, freemarket guru and Nobel Prize winner in economics, dismissed the notion entirely some four decades ago: "Few trends could so thoroughly undermine the very foundations of our free society as the acceptance by corporate officials of a social responsibility other than to make as much money for their stockholders as possible." ${ }^{\prime 5}$ More recently, free-market advocates like David Henderson deride CSR as "global salvationism", leading to undesirable regulation of business, raising costs and diminishing both economic freedom and profits. ${ }^{6}$ Indeed, some theoreticians of CSR do argue that powerful corporations should act like citizens, with a moral conscience, being socially responsible because "it is the right thing to do," even if it lowers profits (at least in the short term). ${ }^{78}$ A more middle ground has been taken up by leaders of TNCs belonging to the World Business Council for Sustainable Development; they promote CSR as both good for the world and for business." "Companies do well, in fact, by doing good," by creating "incredible goodwill and customer loyalty". ${ }^{10}$ But TNC leaders insist that CSR be a voluntary gesture, not imposed by governments or international treaties. Thus as the European Commission's "Green Paper" acknowledges: "Most definitions of corporate social responsibility describe it as a concept whereby companies integrate social and environmental concerns in their business operations and in their interaction with their stakeholders on a voluntary basis."11

NGOs are also divided; while many pressure corporations to take up CSR, others are dubious. Anti-globalisation NGOs see the corporate sign-on to the Global Compact, for example, as "bluewash", simply hiding malfeasance behind the UN flag. ${ }^{12}$ Christian Aid wrote a scathing denunciation of CSR initiatives undertaken by Shell, Coca-Cola, and BAT: “...merely a branch of PR...consistently us[ing] CSR to block attempts to establish the mandatory regulation of the companies' activities...saying that regulation is bad for their profits." Christian Aid left no doubt that voluntary CSR "left the worst corporate abusers unrestrained" and called for,

\footnotetext{
...international regulation, backed up by national legislation, to ensure the enforcement of real social responsibility on the corporate world. Introducing the threat of prosecution and legal action, with resulting detailed disclosure of company documents, would create a powerful incentive for companies to behave responsibly. ${ }^{13}$
}

Henderson agrees that many corporations have taken up CSR less out of conviction and more to deflect criticism from NGOs, the commitment being more apparent than real: "...a useful portmanteau description for a wellconsidered present-day business response to suspicion, pressures and attacks." He believes, even so, that this is a naive view and will ultimately damage a free market economy.

Given the apparent enthusiasm for CSR, a whole new industry has grown up around it: academic journals, consultancies, research centres, financial advisors*, business associations, NGOs, and international agencies. All seek to define and standardise CSR through codes and criteria for social reporting and corporate governance. The European Commission recently analysed a dozen such codes, all varying widely in scope, aspiration, content, and documentation and monitoring. ${ }^{14}$ Such diversity is a result of the voluntary nature of CSR over a broad range of industries.

A leading CSR code is the AAl000S Assurance Standard developed by the Institute of Social and Ethical Accountability (a consulting firm deriving income from corporate, NGO, and individual "memberships" and sale of services). Its set of criteria is based on "stakeholder engagement...[and] organisational responsiveness" to stakeholder concerns. ${ }^{15}$ Another leading code, the Global Reporting Initiative (GRI) originated with the United Nations Environment Program (UNEP) and the NGO Coalition for Environmentally Responsible Economies (CERES). ${ }^{16}$ GRI's "Sustainability Reporting Guidelines" is oriented to corporate behaviour in six categories: economic impacts, environment, labour practices, human rights, business ethics, and product responsibility. In the latter are included "customer health and safety" and advertising. BAT's two annual social reports have selected elements of both the AA1000 and GRI standards.

Management theory on stakeholders proposes that large corporations have obligations beyond the traditional stockholder: "social contracts" with customers, suppliers, employees, trade associations, political groups, NGOs, governments, communities, among others. A standard business school textbook provides numerous case studies to show that fiduciary responsibility accrues equally to stakeholders as to shareholders, and that an ethical responsibility to stakeholders requires corporations "not to harm, coerce, lie, cheat, steal...". ${ }^{17}$ Stakeholders are a principal focus of social responsibility declarations by both PM and BAT. Whether BAT even made a fair application of the stakeholder principle has been vigorously questioned by Action on Smoking and Health (ASH UK). ${ }^{18}$

One economic incentive for voluntary CSR is several dozen "social responsibility investment" stock portfolios that screen against certain corporations and industries, socalled "social funds". ${ }^{19}$ A typical example is the FTSE4Good index fund portfolio that does not hold stocks in the tobacco, weapons, nuclear power, and various mineral extracting and processing industries. ${ }^{20}$ The Dow Jones Sustainability Index (DJSI), however, while considered an SRI fund, invests in companies able to avoid environmental and social disasters, and so to keep a business robust. ${ }^{21}$ John A Prestbo, editor of Dow Jones Indexes, dismissed social responsibility as a "negative perspective". From an investor's point-of-view, he avers, sustainability should focus primarily on increasing shareholder value. "Another way of putting it would be that sustainability delivers fewer negative surprises." ${ }^{\prime 22}$ BAT is

*Including the International Centre for Corporate Social Responsibility at the University of Nottingham, UK, funded by British American Tobacco. 
the first, and so far only, tobacco company listed on the DJSI. $^{\dagger}$

The 1990s were a decade full of "negative surprises" for the tobacco industry: multiplying law suits, discovery and release of millions of pages of internal company documents, increasing restrictions on public smoking, legislative investigations, and growing political pressures to regulate the industry; all had dire implications for investor confidence and share price. The average citizen already had a low opinion of the industry, as illustrated by a survey conducted for PM in 2000..$^{23}$ Thus like other major corporations in trouble, both BAT and PM turned to the concept of CSR. PM has not issued a formal social report, choosing to declare its responsibilities on its web pages, while BAT has published two. ${ }^{\ddagger}$ How PM explored and formulated its version of CSR is found in the PM company documents, which this report examines. Comparable documents for BAT may exist at the depository in Guildford, UK, but were not searched for. In the end, however, both companies arrived at similar configurations.

\section{METHODS}

Search on the PM documents website (www.pmdocs.com) was conducted between February 2003 and May 2004 by reading all papers found under entries to the index term "filename" that appeared relevant to CSR. "Files" are those collections of documents belonging to individuals at PM, and the relevant terms were discovered by the snowball technique, trawling for names of principals in PM responsible for the several initiatives carried out under these headings. The file terms included "CSR", "corporate responsibility", "corporate social responsibility", "social responsibility", "social reporting", "corporate codes", "PM2l" [Philip Morris 21st century], "strategic issues task force", "issues management", "PM USA CRT-CWRT [Corporate Responsibility Team, Corporate Responsibility Working Team]", "Altria" (the new parent name for PM Companies), among others. Several hundred documents reviewed included emails, memoranda, letters, reports (in draft and final forms), presentations and transcripts; exemplars are provided. One useful document written by PM executive staff is a comprehensive 114 page summary of the development of the CSR stance. ${ }^{24}$

\section{FINDINGS: PM CSR DEVELOPMENT}

PM has chosen to present itself as an ethical business. In 1996 its CEO Geoffrey Bible defended the company in an address to its employees:

I believe passionately that we are right, and let me tell you why. We are right because for millions of people, smoking is part of an adult lifestyle... We are right because cigarettes are a legal product... What some people may not understand is that we are an ethical company. Our tobacco business may be controversial, but we are principled people who are honest and straight-dealing... That is an absolutely critical part of our corporate culture. ${ }^{25}$

PM set about to turn Bible's private manifesto into a public pronouncement.

†Contrariwise, there is also a "vice fund" for tobacco, alcohol, gambling and weapons corporations' shares. BAT and Altria/Philip Morris are top performers. http://www.vicefund.com/.

‡See www.britishamericantobacco.com, "social report" and "download centre"

\section{"More than just a tobacco company"}

In 1997, at the height of lawsuits brought against the tobacco industry by US states attorneys general, PM designed a public relations strategy, "PM21", intended to burnish the company's image by stressing its humanitarian and environmental good works: "PM Advertising Objective: Improve favorability of the Philip Morris Company by showing the American public who we really are... Give people reasons to connect with PM on a positive, emotional level." ${ }^{26}$ Then in 1998, the Master Settlement Agreement (MSA) with the attorneys general provided PM and other major cigarette companies the relief of not having to face dozens of state sponsored lawsuits in exchange for cash, changes in marketing and advertising, and guaranteed release of industry documents. Steven Parrish, senior vice-president corporate affairs, PM Companies, and General Counsel, in a "mea culpa" before a Rotary audience in 2001, credited the MSA with prompting the new, socially responsible approach:

...my company's public reputation has taken quite a pounding over the last decade or so... we have no one to blame for that but ourselves... Public concerns were mounting over the serious health effects of tobacco use. People were worried about problems like youth smoking... Our response to this shifting social climate was silence and inaction. By refusing to engage in a dialogue with society in an effort to resolve legitimate concerns and solve real problems, we only succeeded in making them worse... The tobacco environment changed dramatically in the U.S. in 1998. The major U.S. tobacco companies... reached a sweeping agreement with the state attorneys general... What's truly significant is that it ushered in an era of fundamental and lasting change in the way cigarettes are marketed and sold. ${ }^{27}$

An outside analyst had warned Parrish in 1999 that the MSA notwithstanding PM's company image was still closely linked to the outcome of litigation brought by private citizens, thus to investor confidence and stock price: "In the long run, we believe the tobacco industry's track record in individual suits is the key to valuation... Anti-tobacco groups have demonized the industry and influenced juries (as witnessed in San Francisco and Oregon) while the industry hid behind closed doors." The analyst advised that PM21 should advertise the company "as being more open and accessible, as working to reduce youth smoking both domestically and internationally, and as being supportive of reasonable solutions to the public policy issues facing cigarette manufacturers". Apologies for past behaviour, however, were thought not to be an "effective form of communication". Instead, PM should highlight all the good all the PM companies did, such as hunger and disaster relief, youth smoking prevention, campaign against domestic violence. PM s would be revealed as a "good corporate citizen... [M]ore than just a tobacco company.,"28

\section{Dealing with "strategic issues"}

Geoffrey Bible recognised that image remake and philanthropy would not be enough; the product—cigarettes—was still the main issue. In May 1999 he convened a "Strategic Issues Task Force" to consider how the company's new web page should explain its "position on the subjects of causation, addiction, and Environmental Tobacco Smoke, and whether the Company should disclose ingredient information on the web site, and if so, in what form." Such potential statements to the US audience might serve to "enhance our public communications on various issues that are topical in our domestic tobacco business." ${ }^{29}$ Denise Keane, PM USA senior 
vice president and General Counsel, was put in charge of the task force. She soon reported back to Bible that "The Task Force recommends using the Worldwide Web as a central platform for communicating on our core tobacco (and other) issues-including addiction, causation, ingredients, and ETS." She pointed out that while "most users will be American, the Web Site will be available internationally and can have international ramifications. We need, therefore, to communicate tobacco issues in a way that is consistent and 'global'."'30

William Webb, chief operating officer of PM Companies, agreed that there existed a "global regulatory environment" whose "geographic breadth...has critical implications especially for our international tobacco business" ${ }^{\prime \S}$ and thus proposed that the Strategic Issues Task Force expand its role beyond a public relations effort to actually develop global company policy around youth smoking prevention, marketing and advertising, product regulation, reduced risk products, and information on the website. ${ }^{31}$

\section{Corporate responsibility: using social and environmental issues as a shield against "wolves at the door"}

David Nicoli, a member of the task force, was PM's vice president for "issues management" and "strategy and social responsibility". ${ }^{32}$ He argued that as a global, multi-faceted corporation PM had to be concerned about issues beyond tobacco, such as child labour, human rights, and the necessity to create corporate codes of ethical conduct in order to stave off anti-corporate attacks. Sometime in 2000 he wrote a long memorandum to Steve Parrish and Charles Wall (vice president for litigation and Deputy General Counsel PM Companies) asking for a new corporation wide task force to deal with the matter: "Only with a systematic and iterative process can the company have a reasonable degree of assurance that it will not be 'blindsided' by 'stealth issues' that may cause us financial or reputational harm."

Parrish and Wall then wrote to William Webb and Geoffrey Bible, honing the rationale offered by Nicoli to promote CSR as an active defence:

\section{We believe that the Company must become more systematic in managing political and social issues that can impact our business result, shareholder value, corporate reputation, and/or our position in litigation controversies. [W]e believe that "corporate issues man- agement" must now look beyond the wolves at the door on just the tobacco business and begin to deal with the wolves that are likely to come to the door because of the full breadth of our global business... We need to get ahead of the curve on public expectations of a corpora- tion. That will reduce the risks of law suits and improve our standing, when we are sued, as a "responsible corpora- tion"... As a "leading global consumer products com- pany", we need to act like our peers in the evolving area of "corporate social responsibility". Otherwise, we will stand out as a target and will be vulnerable where we have "weak links." 34}

The promising issues Parrish and Wall identified included ethical trade, labour standards, biotechnology, waste management, and "responsible marketing". They allowed that "responsible marketing" could not permit double standards, one domestic USA, another international, either in food or tobacco. "We all know how explosive these issues can be."

$\S$ Webb may have been referring to the development of the WHO Framework Convention on Tobacco Control (FCTC).
The track then diverged. The PM International "Corporate Issues Project" looked at corporate matters such as labour standards, commerce and trade, agriculture and environment; and political topics such as tort, health care and campaign finance reforms-that is, all issues susceptible to legislation and regulation; ${ }^{35}$ while PM USA established a "Corporate Responsibility Taskforce" to explore developing a social report, the public statement of CSR, on which this paper focuses. The "discovery" process was largely driven by mid-level managers.

\section{Corporate social responsibility: also a means to engage employees}

The desire for respect both within and outside the company played a dominant role in all the taskforce's deliberations. In an initial meeting in October 2000, the taskforce listed certain outcomes expected of corporate responsibility, including "Competitive advantage... We would be one of the 'Top 10' most admired companies... More informed employees." The team's members also addressed certain parlous topics: "Admit our mistakes - quit 'dancing'... Our unique issue is the health impact of our product... but also our history and the public's perception that we lied to them. ${ }^{1{ }^{36}}$ In a follow up meeting, several statements addressed the employees' role as stakeholders, and their bewilderment:

As far as being ambassadors, it's tough because we feel defensive and lack information and understanding of some things we're attacked on... Prepare for widespread employee emotional conflict (employees are all over the map). We have to acknowledge that we have a pastwhat we do, we don't know yet, but there has to be a healing. ${ }^{37}$

At a follow up meeting, the company's core mission was elaborated as the preamble to a social responsibility statement:

Our goal is to be the most responsible, effective, and respected developer, manufacturer, and marketer of consumer products, especially products intended for adults. Our core business is manufacturing and marketing the best quality tobacco products available to adults who choose to use them.

Nine goals were outlined, most dealing with stakeholders. Of key importance was Goal 2: "Protect the rights of adults who choose to smoke while continuing to work to reduce health risks associated with smoking...reducing the health risks is one of the most important initiatives in the company." 38

In the spring of 2001 the taskforce continued with what was called a "conversation" about corporate responsibility and to reshape the statement of goals into final form. Fifty five mid level executives from various divisions of PM USA participated. Unlike the earlier deliberations notes from this session show virtually no concern for the past or doubt. Within a set of "working notes" in preparation for a final presentation to top executives one finds overarching company policies held to closely: "It is confirmed that the Revised Goal Statements are consistent with positions the company is taking in litigation." ${ }^{39}$ In none of the documents reviewed were the words "death" or "mortality" ever used. ${ }^{40}$

An anonymous PM executive interpreted the recommendations of the taskforce to emphasise the role of stakeholders, and the smoker as the "key stakeholder": 
Corporate responsibility is not just about reputation... [C]orporate responsibility is much more about behavior than it is about communications and image.... Clearly for us issues relating to our product... are the biggest concern, but one of the things we learned is that we can not simply focus on our product issues if we want to be responsible... [emphasis added] Stakeholder engagement...turns out to be a very critical part of responsible behavior-the willingness to talk to stakeholders about what they want from a company and what they believe responsible behavior to be... The key stakeholder-our adult consumer.... It's not just about product-it's about all aspects of our operations, up and down the value chain, looking at all the impacts from what we do. ${ }^{41}$

\section{The corporate responsibility put into operation: the "game plan"}

To implement the taskforce recommendations a Corporate Responsibility Team was established in late 2001: 11 senior persons drawn from the compliance, market information, human resources, and corporate responsibility divisions, to make the CSR communications plan operational. Key stakeholders were identified. Included among the strategies for the first time was the intention to acknowledge specific hazards of smoking:

Help Reduce Youth Smoking...Market Our Products Responsibly...Communicate the Health Effects of Our Products...Provide Smoking Pleasure/Reduce Harm...Support Reasonable Regulation...Comply with Legal and Regulatory Requirements... Value Our Employees...Engage with Our Business Partners... Reduce Environmental Impact...Play an Active Role in Community Development...Provide Shareholder Return. ${ }^{42}$

\section{Altria, not just a tobacco company; a vehicle for doing good \\ PM Companies are now known as Altria, a faux word: "Altria, derived from altus, meaning high, symbolizes for us a company that is already great, but reaching ever higher," as announced in a pamphlet released on 1 November 2001. The declaration went on: "Altria also represents our continuing commitment to being socially responsible and to aligning our thoughts and actions with the common good of the communities we serve" ${ }^{43}$ The purpose and value of the new corporate name were confirmed by James Spector, head of corporate identity strategies and practice, and chair of a Global Corporate Affairs Council (GCAC) committee on "global image enhancement." He indicated that "Altria" would take up the mantle of social responsibility:}

While on the face of it, it is just a name change, we also have the opportunity to highlight many of the initiatives that were already in place under PM Cos. Inc. but were unable to breakthrough because of the name confusion. We can begin to focus attention away from tobacco, and on to compliance, responsibility, philanthropy, environment, etc., all the things we want Altria to be identified with... ${ }^{44}$

\section{To code or not to code}

In the previously cited memo to Bill Webb and Geoff Bible in late 2000, Steve Parrish and Charles Wall had reflected on the spate of official corporate codes of conduct:

\section{What this paper adds}

Like other transnational corporations that impact society, the environment and human health, two major tobacco companies have sought to regain the public's respect and investor confidence by embracing the principle of "corporate social responsibility" (CSR). This report explains the theory and process of CSR, and then documents how one company, Philip Morris, created its CSR statement, and the principal corporate reasons for doing so: to restore its battered reputation, maintain employee morale, mitigate future lawsuits, and thereby to increase the value of corporate stock. While many corporations may have similar motives, the result of their social reports may be favourable to the environment and society. This paper concludes that being in the cigarette business, however, is antithetical to CSR.

Most major corporations are joining one or several of these Codes, and certain institutional investors, such as public pension funds and universities are under pressure to use the Codes as 'screeners' for investment. We need to examine whether PM should or should not sign up to any of these codes. (We may not even been [sic] 'acceptable' to some. $)^{34}$

In fact, Karen Daragan of PM Management Corporation (PMMC) and director of social responsibility and corporate issues, asked Sustainable Asset Management, the Swiss social investment partner of the DJSI, to conduct an informal assessment of PM measured against the DJSI criteria, which included several items related to the tobacco industry. She reported to upper management: "We did not fill out the DJSI survey. The results were not great for those reasons and others." ${ }^{45}$

Unlike BAT, PM has not written a formal social report following code criteria, has not signed on to any existing code, or been listed in any social investment portfolio. Instead, the company appears to have taken the written advice of one of its CSR consultants, Business for Social Responsibility, underlined and starred by a PM reader, that many corporations are "publishing the information on their Web sites, and some are choosing to only put it on their Web sites." ${ }^{\prime 6}$ The Altria web site contains a message from Karen Daragan (now vice president, strategy and social responsibility, Altria Corporate Services, Inc) that begins:

What we within the Altria family of companies call Responsibility goes by many other names around the globe-Corporate Social Responsibility, Corporate Citizenship, Sustainable Development, or Managing for the Triple Bottom Line. We believe that the name chosen is less important than the core concept. ${ }^{47}$

PM USA's current web site gives the "Mission \& Values" list as finally decided on in the development of approach to CSR. The site makes statements unimaginable coming from PM just a couple of years ago. It is explicit about the diseases caused by smoking (although without using the words "death" or "mortality"); accepts that "cigarette smoking" is addictive (but without mentioning nicotine); and provides detailed lists of ingredients potentially present in all its brands. With respect to passive smoke: "Philip Morris USA believes that the public should be guided by the conclusions of public health officials regarding the health effects of secondhand smoke." ${ }^{\prime 4}$ A new web page has been posted in 
2004 detailing the research PM scientists have published or presented on harm reduction, cigarette toxicology, and other studies. ${ }^{49}$ The PM International website quotes its president and CEO, Andre Calantzopoulos, saying: “...for us economic performance is not the only measure of our success. Honesty, integrity and social responsibility are just as important to the way we measure ourselves"; the technical details about smoking and cigarettes scattered about the site closely match PM USA's. ${ }^{50}$ In all these sites PM information is more forthcoming than what is present at RJ Reynolds and Japan Tobacco International sites where no claims to CSR are made.

\section{DISCUSSION}

The documents reviewed in this paper show how PM developed public statements based on concepts of CSR; it is not unlikely that internal documents of other TNCs espousing CSR would show similar processes. PM executives maintain that their company has always been ethical and responsible, but realised that public relations statements and philanthropy were insufficient to stem the tide of investigation, litigation, internal documents coming to light, diminished employee morale, and eroding share value. Under its own terms, as a corporate entity, PM justifiably used the concept of CSR to maintain its responsibility to its principal stakeholder, the investor; documents aimed at an internal audience are congruent with statements made in public, an unusual finding in documents research. But in its approach to social responsibility, PM also claims that one of its key stakeholders is the "adult smoker" who makes the informed choice to smoke; and that the company must defend this right of choice. But here is the dilemma. This corporate entity has a profound and disturbing effect on the public's health with a product that kills half its users, as well as a smaller proportion of non-users exposed to secondhand tobacco smoke. Moreover, the alleged right to choose to smoke is undermined by the company's forthright admission that its product is addicting, and made deliberately more so as industry documents show ${ }^{51}$; that the majority of American smokers wish they did not ${ }^{52}$; and, disturbingly, that nearly half the tobacco consumed in the USA is by persons with mental illness..$^{53}$ No other major corporation espousing CSR is so burdened. While the literature and case studies on CSR mostly support the positive contributions of major industries to social responsibility, one must conclude that being in the cigarette business is antithetical to CSR.

So, as Kenneth Warner asked: what is a tobacco company to do? PM replies that with respect to CSR, it is seeking to make smoking less hazardous; it wishes to market responsibly to informed, willing adults only; and it is responsive to all its stakeholders, including the scientific and public health communities. Warner, doubting the industry's bona fides, proposed that the tobacco industry be truly responsible by abandoning advertising and promotion, supporting a huge increase in the excise tax, turning youth prevention programmes over to a neutral agency, and accepting effective regulation by the federal government. Most importantly, he called on the industry to cease the "bald and voracious attempts to expand its market among the world's most vulnerable populations" ${ }^{\prime 54}$ In other words, stop behaving like an ordinary free enterprise corporation. PM executives, struggling to improve the company's image, actually debated in the early 1990s getting out of the cigarette business altogether, but demurred. ${ }^{55}$ It would have been better had they done so.

Given an industry that intends to remain in the cigarette business for the foreseeable future, what are tobacco control advocates to do? They must maintain the pressure for bans on public smoking, higher taxes, counter-marketing, effective regulation, litigation, improved methods of cessation, and for ratification of the Framework Convention on Tobacco Control. Also essential is to caution the public against uncritical acceptance of the tobacco industry's mantle of "social responsibility".

\section{ACKNOWLEDGEMENTS}

Stella Blalous and Stan Shatenstein provided helpful reviews of the paper in draft.

\section{REFERENCES}

1 Crowther D, Rayman-Bacchus L. Chapter 1, Introduction: perspectives on corporate social responsibility. In: Crowther D, Rayman-Bacchus L, eds. Perspectives on corporate social responsibility. London: Ashgate Publishing Ltd, 2004.

2 McKie JW. Chapter 2, Changing views. In: McKie JW, eds. Social responsibility and the business predicament. Washington DC: The Brookings Institute, 1974.

3 Boatright JR. Ethics and the conduct of business, 4th ed. Upper Saddle River, New Jersey: Prentice Hall, 2003:372.

$4 \mathrm{http}: / /$ www.unglobalcompact.org/Portal/Default.asp [Accessed 21 May 2004].

5 Friedman M. Capitalism and freedom. Chicago: University of Chicago Press, 1962:133.

6 Henderson D. Misguided virtue: false notions of corporate social responsibility. London: Institute of Economic Affairs, 2001.

7 Goodpaster KE, Matthews JB Jr. Can a corporation have a conscience? Harvard Business Review on Corporate Responsibility. Cambridge: Harvard Business School Publishing Co, 2003:27-64.

8 Martin RL. The virtue matrix: Calculating the return on corporate responsibility. Harvard Business Review on Corporate Responsibility. Cambridge: Harvard Business School Publishing Co, 2003:83-103.

9 Holliday CO Jr, Schmidheiny S, et al. Walking the talk: the business case for sustainable development. San Franciso: Berret-Koehler Publishers, Inc, 2002.

10 Lear N, ('doing good"), Burke JE, ("goodwill')), cited in Bollier D. Aiming higher: 25 stories of how companies prosper by combining sound management and social vision, New York: American Management Trust, 1997; viii 5-6.

11 European Commission. Promoting a European framework for corporate social responsibility. Green Paper. European Commission DirectorateGeneral for Employment and Social Affairs, July 2001. http://europa.eu.int/ comm/employment_social/soc-dial/csr/csr_index.htm [Accessed 10 May 2004].

12 Ruggie JG. Corporate social responsibility and the global compact. Journal of Corporate Citizenship 2002;5:27-36.

13 Christian Aid. Behind the mask. The real face of CSR. 2004: 2-3, http:// www.christianaid.org.uk/indepth/0401 csr/index.htm [Accessed 3 May 2004].

14 European Commission. Mapping instruments for corporate social responsibility. European Commission Directorate-General for Employment and Social Affairs. April 2003. http://europa.eu.int/comm/ employment_social/soc-dial/csr/csr_index.htm [Accessed 10 May 2004]

$15 \mathrm{http}$ ///www.accountability.org.uk/aa1000/default.asp [Accessed 14 May 2004].

16 http://www.globalreporting.org/ [Accessed 15 May 2004]

17 Carroll AB. Business and society: Ethics and stakeholder management, 3rd ed. Cincinnati: South-Western College Publishing, 1996:78.

18 Shatenstein S. BAT social report revisited: ASH comes to BAT. 2002. http:// www.ash.org.uk/ [Accessed 17 May 2004]

19 http://www.socialfunds.com/ [Accessed 16 May 2004].

20 www.ftse.com/ftse4good/index.jsp [Accessed 9 May 2004], A long roster of companies on the index may be found under "full constituent list. ".

$21 \mathrm{http}: / /$ www.sustainability-indexes.com/Link to "About Us," then to "Sustainability" [Accessed 15 May 2004].

22 http://web.archive.org/web/20030524050103/www.sbi-w.com/sbi-a/ sept2001/dowjones.htm [Accessed 18 May 2004]

23 Anon. "Philip Morris USA Corporate Reputation: Benchmark Study." July 2000. Philip Morris. Bates No. 2080771817/1840. www.pmdocs.com/ getallimg.asp? if = avpidx\&DOCID = 2080771817/1840 [Accessed 6 November 2003].

24 PM USA Corporate Responsibility Taskforce. Draft CRT working notes synthesis. March 2001. Philip Morris. Bates No. 2085299379/9491. www.pmdocs.com/getallimg.asp? if = avpid $\&$ DOCID $=2085299379 / 9491$ [Accessed 1 May 2004]

25 Bible GC. Remarks.Meeting With Employees. 9 April 1996. Philip Morris. Bates No. 2048334067/4075, at-4073/4. www.pmdocs.com/ getallimg.asp? if $=$ avpidx\&DOCID $=2048334067 / 4075$ [Accessed 16 May 2003].

26 Anon. PM 21 'Making A Difference' Story Development. 1997. Philip Morris. Bates No. 2081612815/2816. www.pmdocs.com/getallimg.asp? if $=$ avpidx\&DOCID $=2081612815 / 2816$ [Accessed 8 November 2003]

27 Steven Parrish. Speech to the Rotary Club of Pittsburgh. June 202001 . Philip Morris Bates No. 2081688803/8820. www.pmdocs.com/getallimg.asp? if $=$ avpid $x \& D O C I D=2081688803 / 8820$ [Accessed 16 May 2004]

28 Sanford C Bernstein \& Co, Pecoriello B. Philip Morris Image Campaign is Part of Long Term Solution, No Quick Fixes; Outperform. 13 October 1999. Philip Morris. Bates No. 2065594267/4277, at -4267-9/72. www.pmdocs.com/ 
getallimg. asp?if $=$ avpid $x \& D O C I D=2065594267 / 4277$ [Accessed 16 May 2003].

29 Bible GC. Strategic Issues Task Force. Memorandum to Distribution. 12 May 1999. Philip Morris. Bates No. 2044437914/7915. www.pmdocs.com/ getallimg. asp? if $=$ avpid $\&$ DOCID $=2044437914 / 7915$ [Accessed 29 April 2003].

30 Keane DF. Strategic Issues Task Force: Interim Report. Memorandum to GC Bible. 18 June 1999. Philip Morris. Bates No. 2044438368/8371, at-83689. www.pmdocs.com/getallimg. asp?if $=$ avpid $\& D O C I D=2044438368$ / 8371 [Accessed 29 April 2003].

31 Webb WH. Strategic Issues Task Force. Memorandum to "Distribution. 27 January 2000. Philip Morris. Bates No. 2073814540/4541. www.pmdocs.com/getallimg. asp? if $=$ avpid $\&$ DOCID $=2085293994 / 3995$ [Accessed 26 February 2003].

32 Anon. PM USA Corporate Responsibility Task Force. November 1999. Philip Morris. Bates No. 2078877176. www.pmdocs.com/ getallimg. asp? if $=$ avpidx\&DOCID $=2078877176$ [Accessed 7 March 2003]

33 Nicoli D. Re: Management of Corporate Issues. [Second] Draft Memorandum to Steve Parrish and Chuck Wall. 2000. Philip Morris. Bates No. 2085292281/2286, at-2281. www.pmdocs.com/ getallimg. asp? $\mathrm{if}=$ avpidx\&DOCID $=2085292281 / 2286[$ Accessed 26 February 2003].

34 Parrish S, Wall C. Management of Corporate Issues. Memorandum [draft 1 ] to Bill Webb and Geoff Bible. 2000. Philip Morris. Bates No. 2085292292/ 2298, at-2292,-2294,-2296/7. www.pmdocs.com/ getallimg. asp? $i \mathrm{f}=$ avpid $\& \mathrm{DOCID}=2085292292 / 2298$ [Accessed 26 February 2003].

35 Nicoli D (inferred). Corporate Issues Project. 31 October 2000. Philip Morris. Bates No. 2085292346/2362. www.pmdocs.com/ getallimg.asp? if $=$ avpidx\&DOCID $=2085292346 / 2362$ [Accessed 29 April 2003].

36 Anon. Corporate Responsibility Taskforce Kickoff Meeting.draft meeting notes." 23-25 October 2000. Philip Morris. Bates No. 2081455398/5414, at-5408/9, -5413. www.pmdocs.com/

getallimg .asp? if $=$ avpid $\&$ DOCID $=2081455398 / 5414$ [Accessed 5 March 2003].

37 Anon. Corporate Responsibility Taskforce Discovery Phase.draft meeting notes. 11-12 January 2001. Philip Morris. Bates No. 2081454961/4997, at-4983,-4997. www.pmdocs.com/ getallimg. asp? if $=$ avpid $\&$ DOCID $=208145496] / 4997$ [Accessed 8 May 2003].

38 Anon. PM USA Corporate Responsibility Discovery Phase. Working Notes. 14-16 February 2001. Philip Morris. Bates No. 2080384147/4198, at 4175. www.pmdocs.com/ getallimg. asp? if $=$ avpid $\times \& D O C I D=2080384147 / 4198$ [Accessed 26 April 2003].

39 Anon. PM USA Corporate Responsibility Taskforce Working Notes. 17 July 2001. Philip Morris. Bates No. 2085624396/4414, at-4403. www.pmdocs.com/getallimg. asp? $i f=$ avpidx\&DOCID $=2085624396 / 4414$ [Accessed 8 May 2003].

40 A draft of deliberations by nineteen upper level managers was extensively marked up by hand by assistant general counsel John Holleran. A phrase used, "cradle to grave product stewardship," drew this marginal comment: "Given youth issues \& health issues associated with this product, I'm not sure this is the best way to capture the thought." "Corporate Responsibility
Taskforce Discovery Phase," 11-12 January 2001. Philip Morris. Bates No. 2081454961/4997, at-4972. www.pmdocs.com/

getallimg . asp? if $=$ avpid $\&$ DOCID $=2081454961 / 4997$ [Accessed 29 April 2003].

41 Anon. A Conversation About Corporate Responsibility. PM USA Corporate Responsibility Taskforce Presentation for the 2002 Game Plan. 2001

(probable). Philip Morris. Bates No. 2085299856/9885, at-9862, -9864, 9886, -9872-3, -9887, -9889. www.pmdocs.com/ getallimg.asp?if $=$ avpidx\&DOCID $=2085299856 / 9885$ [Accessed 29 April 2003].

42 Anon. PM USA Corporate Responsibility Team Work-In-Progress Synthesis and Project Update/Working Session. 19 November 2001. Philip Morris. Bates No. 2085127639/7663, at -7645 . www.pmdocs.com/ getallimg.asp? if $=$ avpidx\&DOCID $=2085127639 / 7663$ [Accessed 29 April 2003]

43 Philip Morris. Pamphlet. A new name for global leadership. 1 November 2001. Philip Morris. Bates No. 2085241635/639A, at -1638 . www. pmdocs.com/getallimg. asp?if $=$ avpid $\& D O C I D=2085241635$ / 1639A [Accessed 18 May 2003]

44 Spector J. Direction for Altria. 30 November 2001. Philip Morris. Bates No. 2085246857. www.pmdocs.com/

getallimg.asp?if=avpidx\&DOCID = 2085246857 [Accessed 18 May 2003]

45 Daragan K. Subject: Dow Jones Sustainability Index: Food and Tobacco Assessment Methodology. Email to various persons. 23 January 2002. Philip Morris. Bates No. 2085783025C/3026. www.pmdocs.com/ getallimg. asp? $\mathrm{if}=$ avpid $\&$ DOCID $=2085783025 \mathrm{C} / 3026$ [Accessed 26 April 2003].

46 Philip Morris. Business for Social Responsibility. Social Reporting Primer. August 2001. Philip Morris. Bates No. 2085127422/7435, at -7435 . www.pmdocs.com/getallimg.asp? $i f=$ avpidx\&DOCID $=2085127422 / 7435$ [Accessed 25 February 2003].

47 Daragan K. The Company's commitment to responsibility. January 28, 2003. [Accessed 16 May 2004, via hitp://www.altria.com/default.asp, "Responsibility Overview. Point of View Greenberg. Archive". http:// www.altria.com/media/executive_speech/ 03_09_04_03_KDaragan01282003.asp.

48 Philip Morris USA. http://www. pmusa.com/home.asp [Accessed 16 May 2004].

49 Philip Morris USA. http://www.pmusa-science.com/Home.asp [Accessed 17 May 2004].

50 Philip Morris International. http://www. philipmorrisinternational.com/ [Accessed 16 May 2004]

51 Hurt RD, Robertson CR. Prying open the door to the tobacco industry's secrets about nicotine JAMA 1998;280:1173-81.

52 Centers for Disease Control and Prevention. Cigarette smoking in adults United States, 2000. MMWR Morb Mortal Wkly Rep. 2000;51: 642-45, http://www.cdc.gov/mmwr/preview/mmwrhtml/mm5129a3.htm American Legacy Foundation : http://www.no-smoking.org/july03/07-17-03-4.html [Accessed 17 May 2004], (reported by ASH).

53 Lasser K, Boyd JW, Woolhandler S, et al. Smoking and mental illness. A population-based prevalence study. JAMA 2000;284:2606-10

54 Warner KE. What's a cigarette company to do? Am J Public Hlth 2002; $92: 897-900$

55 Smith EA, Malone RE. Thinking the 'unthinkable': why Philip Morris considered quitting. Tobacco Control 2003;12:208-13. 